\title{
Brazilian Sign Language teaching in undergraduate nursing courses
}

\author{
Ensino da Língua Brasileira de Sinais nos cursos de graduação em enfermagem \\ Enseñanza del Lenguaje Brasileño de Signos en cursos de graduación en enfermería
}

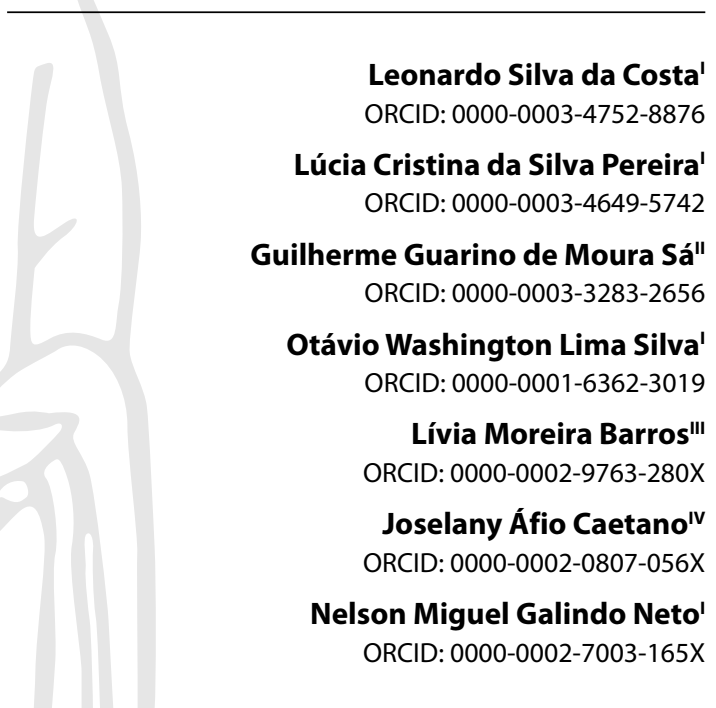

'Instituto Federal de Educação, Ciência e Tecnologia de Pernambuco. Pesqueira, Pernambuco, Brazil. "Instituto Federal de Educação, Ciência e Tecnologia de Pernambuco. Belo Jardim, Pernambuco, Brazil. "'Universidade da Integração Internacional da Lusofonia Afro-brasileira. Redenção, Ceará, Brazil. "Universidade Federal do Ceará. Fortaleza, Ceará, Brazil.

How to cite this article: Costa LS, Pereira LCS, Sá GGM, Silva OWL, Barros LM, Caetano JÁ, et al. Brazilian Sign Language teaching in undergraduate nursing courses. Rev Bras Enferm. 2021;74(Suppl 5):e20200709. https://doi.org/10.1590/0034-7167-2020-0709

Corresponding author: Nelson Miguel Galindo Neto E-mail: nelsongalindont@hotmail.com

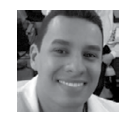

EDITOR CHEFE: Dulce Barbosa EDITOR ASSOCIADO: Marcia Magro

\begin{abstract}
Objective: to characterize the Brazilian Sign Language teaching in undergraduate nursing courses. Method: a cross-sectional study, carried out on the curriculum matrices of 553 higher education nursing courses. Data collection took place through access to the websites of the Ministry of Education and educational institutions. Results: the nursing courses that offered Libras were located predominantly in the Southeast (36\%), coming from private institutions (87.2\%). Most Libras courses (82\%) were offered on a mandatory basis in the second half of the course (46.7\%). The semester in which the offer was most frequent was the eighth $(15.9 \%)$. There was an association $(p<0.001)$ between the offer of course and the variable "public or private category". Conclusions: there was a predominance of Libras course in private institutions, in the Southeast region, with a 40-hour workload, offered in the second half of the course.

Descriptors: Education, Nursing; Education, Nursing, Baccalaureate; Education, Higher; Sign Language; Curriculum.
\end{abstract}

\section{RESUMO}

Objetivo: caracterizar o ensino da Língua Brasileira de Sinais nos cursos de graduação em enfermagem. Método: estudo transversal, realizado nas matrizes curriculares de 553 cursos superiores de enfermagem. A coleta dos dados ocorreu por meio do acesso aos websites do Ministério da Educação e das instituições de ensino. Resultados: os cursos de enfermagem que ofereciam disciplina de Libras se localizavam, predominantemente, no Sudeste (36\%), oriundos de instituições privadas $(87,2 \%)$. A maioria das disciplinas de Libras (82\%) foi ofertada, de forma obrigatória, na segunda metade do curso $(46,7 \%)$ e o semestre no qual mais ocorreu a oferta foi o oitavo $(15,9 \%)$. Houve associação $(p<0,001)$ entre a oferta de disciplina e a variável "categoria pública ou privada". Conclusões: houve predomínio de oferta de disciplina de Libras em instituições privadas na Região Sudeste, com carga horária de 40 horas, ofertada na segunda metade do curso.

Descritores: Educação em Enfermagem; Bacharelado em Enfermagem; Educação Superior; Línguas de Sinais; Currículo.

\section{RESUMEN}

Objetivo: caracterizar la enseñanza de la Lengua de Signos Brasileña en cursos de pregrado en enfermería. Método: estudio transversal, realizado en las matrices curriculares de 553 cursos de enfermería de educación superior. La recopilación de datos se realizó mediante el acceso a los sitios web del Ministerio de Educación y las instituciones educativas. Resultados: los cursos de enfermería que ofrecieron la disciplina Libra se ubicaron predominantemente en el Sureste $(36 \%)$, provenientes de instituciones privadas ( $87,2 \%)$. La mayoría de las asignaturas Libras (82\%) se ofertaron, de forma obligatoria, en la segunda mitad del curso $(46,7 \%)$ y el semestre en el que más se presentó la oferta fue el octavo (15,9\%). Hubo asociación ( $p$ $<0,001)$ entre la oferta de disciplina y la variable "categoría pública o privada". Conclusiones: predominó la oferta de la disciplina Libra en instituciones privadas de Sureste, con una carga de trabajo de 40 horas, ofrecida en la segunda mitad del curso.

Descriptores: Educación en Enfermería; Bachillerato en Enfermería; Educación Superior; Lengua de Signos; Curriculum. 


\section{INTRODUCTION}

Worldwide, there are more than 450 million deaf people, and, according to the World Health Organization, by 2050 this number will reach 900 million $^{(1)}$.

Hearing loss greater than $40 \mathrm{~dB}$, with a consequent communication gap, experienced by deaf people, leads individuals to be inserted in a culture different from people with preserved hearing acuity, since communication starts to occur not through auditory sensory perception, but using visual techniques/stimuli ${ }^{(2-3)}$. Thus, effective communication with death people occurs through the use of sign language $\mathrm{e}^{(4)}$.

In the context of health, deaf people have difficulty accessing services and information ${ }^{(5)}$, so that, even among those with high educational level, there is low health literacy ${ }^{(6)}$. This situation is aggravated by the lack of professionals who master the Brazilian Sign Language (Libras) ${ }^{(7)}$, being challenging, since it can compromise prevention, treatment and health rehabilitation.

Limitation of access to information leads deaf people to become dependent on companions or interpreters of Libras to use health services ${ }^{(8)}$ and can be minimized if, since their training, health professionals have the opportunity to contact and learn about the communication in sign language.

Among the professionals who are part of the health team, there is the nurse, whose presence is mandatory in various health services, at all levels of complexity. This broad role of nursing, in assistance, administrative and educational activities, increases the chance of contact with deaf people, with whom you need to establish communication ${ }^{(9)}$.

To transpose the biomedical/curative model and contemplate the demands that arise in health services, nursing education is constantly changing and improving ${ }^{(10)}$. Thus, given the need to communicate with death people, curriculum components about Libras can be made available in higher education nursing courses. However, in the absence of legislation establishing a standard, the profile of Libras courses, offered in nursing baccalaureate courses, is unknown.

When considering that planning and curriculum changes need to occur based on research results, the relevance, relevance and need to characterize the courses related to Libras, offered in undergraduate nursing courses, are pointed out. Such characterization can contribute to the understanding of how such courses are offered, to identify gaps to be addressed in future studies and interventions.

\section{OBJECTIVE}

To characterize the Brazilian Sign Language teaching in undergraduate nursing courses.

\section{METHOD}

\section{Ethical aspects}

As this is not a research carried out with human beings, but with information in the public domain, submission of the project to a Research Ethics Committee with human beings was not necessary; however, it is noteworthy that the ethical aspects regarding the reliability, secrecy and use of data were exclusively respected for scientific purposes.

\section{Study design, place, and period}

This was a cross-sectional, documentary study, with a quantitative approach, carried out according to the Strengthening the Reporting of Observational Studies in Epidemiology (STROBE) recommendations. Data were collected in the computer lab of Instituto Federal de Educação, Ciência e Tecnologia de Pernambuco, Campus Pesqueira, through access to the website of the Ministry of Education (MEC), which presents official information on undergraduate courses, as well as on educational institutions in Brazil. Data collection took place in February 2019.

\section{Population or sample; inclusion and exclusion criteria}

The study population was composed of the curriculum matrices of undergraduate nursing courses at public and private educational institutions. The inclusion criterion adopted was that it is a nursing course curriculum in an active situation, and the exclusion criteria used were: the absence of a curriculum matrix available online and the matrix does not contain the Libras course/component offer.

\section{Study protocol}

For operationalization of data collection, an instrument was elaborated, composed of 20 questions, about variables related to the name, city, state and region of the educational institution; whether it was private or public; with campus located inland or capital; course concepts in MEC; Libras course nomenclature; number of curriculum components that included Libras in the course; the semester/module in which the course was offered; course modality (mandatory or optional) and workload.

Data collection was performed by two researchers, separately, who standardized and trained the search sequence and leveled using the instrument so that there was a comparison of the findings of both, at the end, in which the absence of collection inconsistencies was confirmed, since the results obtained by both were equal. Initially, it was done by accessing http://emec.mec. gov.br/ to search for registered undergraduate nursing courses, authorized by MEC and in an active situation. Thus, a list of 1,221 undergraduate nursing courses was obtained.

Subsequently, collection instrument variables were collected and made available on the website platform (institution's name, acronym and location, whether the institution was private or public, with a campus located in the countryside or capital and concepts of the course). According to information from educational institutions registered with the Ministry of Education, the website of each educational institution was accessed to search for the curriculum matrix of the nursing course.

Of the 1,221 courses checked, 382 (31.3\%) were excluded for not having an available curriculum matrix and 286 (23.4\%), for not having Libras as a curriculum component. Thus, 553 (45.3\%) presented the curriculum matrices available on the institutions' 
website and were selected to compose the sample. In possession of the curriculum matrices of the nursing courses, the variables related to the characteristics of the course offer were collected (Libras course nomenclature; number of curriculum components that included Libras in the course; the semester/module in which the course offer occurred; course modality, mandatory or optional; workload).

\section{Analysis of results, and statistics}

The data were analyzed in a descriptive manner and by checking association in Software R, version 3.5.1. The normality of the numerical variable "workload" was tested by the KolmogorovSmirnov test. Non-adherence to normality was identified so that the variable was presented from the median and interquartile range. The association between the Libras course offer and the "public or private category" variable was verified using Pearson's chi-square test for independence. The adopted significance was $5 \%$ and $95 \%$ confidence interval, in all tests.

\section{RESULTS}

Of the 553 nursing courses that offered the Libras course, 482 (87.2\%) were offered in Private Educational Institutions, and 71 (12.8\%), in Public institutions. The Libras course offer predominated significantly in the private institution in relation to the public institution ( $p<0.001)$. Of these, $52(9.4 \%)$ were Federal Institutions, and 19 (3.4\%), State Institutions. As for the location of the campus, 340 (61.5\%) were located in the interior of the Brazilian states, while 213 (38.5\%) were located in the capitals.

As for geographic location, there was a predominance of Libras courses on offer in the Southeast and Northeast, as detailed in Table 1.

With regard to the concepts of the courses established by MEC, $118(21.3 \%)$ courses did not present such information until the time of data collection. The concept that showed predominance was the three, present in 151 (27.3\%) courses, as shown in Table 2.

In relation to the number of subjects offered, 548 (99.1\%) educational institutions offered a Libras subject, while five (0.9\%) institutions offered two subjects, in the undergraduate nursing course. Regarding the modality, in 455 (82.3\%), the course was mandatory and in 98 (17.7\%), optional.

It was observed that in 191 (34.5\%) courses, the offer of the course does not occur in a specific semester. Of the institutions that have a specific semester to offer the course, the majority $(46.7 \%)$ make this offer in the second half of the course and 88 (15.9\%) more specifically in the eighth semester (Table 3).

The minimum workload for the pounds course was 15 hours, the maximum was 88 hours. The predominant workload, of 40 hours, was found in 218 (39.4\%) undergraduate nursing courses and constituted the median of workloads, with an interquartile interval of 24. The five workloads that were most present in the Libras courses are shown in Table 4.

Five nomenclatures were attributed to Libras: Brazilian Sign Language, in 526 (95.2\%); Topics in Libras, in 15 (2.7\%); Pounds and Inclusion, in six (1.1\%); Death Culture and Libras, in three $(0.5 \%)$; Introduction to Libras, in three $(0.5 \%)$.
Table 1 - Distribution of the Libras course in undergraduate nursing courses by region and state, Brazil, 2019

\begin{tabular}{lcc}
\hline Region/state & $\begin{array}{c}\text { Educational institutions } \\
\mathbf{n ( \% )}\end{array}$ & $\begin{array}{c}\text { Total } \\
\mathbf{n}(\%)\end{array}$ \\
\hline Southeast & $97(17.5)$ & $197(35.6)$ \\
São Paulo & $60(10.8)$ & \\
Minas Gerais & $23(4.2)$ & \\
Rio de Janeiro & $17(3.1)$ & $181(32.7)$ \\
Espírito Santo & & \\
Northeast & $42(7.6)$ & \\
Bahia & $35(6.4)$ & \\
Ceará & $30(5.4)$ & \\
Pernambuco & $15(2.7)$ & \\
Piauí & $15(2.7)$ & \\
Maranhão & $15(2.7)$ & \\
Paraíba & $10(1.8)$ & \\
Rio Grande do Norte & $10(1.8)$ & \\
Sergipe & $9(1.6)$ & \\
Alagoas & & \\
Center-West & $23(4.2)$ & \\
Goiás & $22(4.0)$ & \\
Federal District & $10(1.8)$ & \\
Mato Grosso do Sul & $9(1.6)$ & \\
Mato Grosso & & \\
South & $26(4.7)$ & \\
Rio Grande do Sul & $22(4.0)$ & \\
Paraná & $11(2.0)$ & \\
Santa Catarina & & \\
North & $18(3.2)$ & \\
Pará & $12(2.2)$ & \\
Amazonas & $8(1.4)$ & \\
Rondônia & $4(0.7)$ & \\
Acre & $4(0.7)$ & \\
Tocantins & $3(0.6)$ & \\
Amaá & $3(0.6)$ & \\
Roraima & & \\
\hline
\end{tabular}

Table 2 - Ministry of Education concept of the Institutions that offered Libras in undergraduate nursing courses, Brazil, 2019

\begin{tabular}{lc}
\hline Ministry of Education concept & $\mathbf{n ( \% )}$ \\
\hline Concept unavailable & $118(21.3)$ \\
Concept 1 & $28(5.1)$ \\
Concept 2 & $136(24.6)$ \\
Concept 3 & $151(27.3)$ \\
Concept 4 & $86(15.6)$ \\
Concept 5 & $33(6.0)$ \\
\hline
\end{tabular}

Table 3 - Semesters of undergraduate nursing courses in which Libras is offered, Brazil, 2019

\begin{tabular}{lcc}
\hline Semester offering Libras course & $\begin{array}{c}\text { Institutions } \\
\mathbf{n ( \% )}\end{array}$ & $\begin{array}{c}\text { Total } \\
\mathbf{n ( \% )}\end{array}$ \\
\hline Non-specific semester & $191(34.5)$ & $191(34.5)$ \\
First half of the course & $14(2.5)$ & $104(18.8)$ \\
$\quad$ First semester & $11(2.0)$ & \\
Second semester & $28(5.1)$ & \\
Third semester & $23(4.1)$ & \\
Fourth semester & $28(5.1)$ & \\
Fifth semester & & $258(46.7)$ \\
Second half of the course & $23(4.2)$ & \\
Sixth semester & $52(9.4)$ & \\
Seventh semester & $88(15.9)$ & \\
Eighth semester & $22(4.0)$ & \\
Ninth semester & $73(13.2)$ & \\
Tenth semester & & \\
\hline
\end{tabular}


Table 4 - Hours of Libras in undergraduate nursing courses, Brazil, 2019

\begin{tabular}{lc}
\hline Workload & $\begin{array}{c}\text { Institutions } \\
\mathbf{n}(\%)\end{array}$ \\
\hline 40 hours & $218(39.4)$ \\
60 hours & $129(23.3)$ \\
20 hours & $67(12.1)$ \\
80 hours & $45(8.2)$ \\
Other & $26(4.7)$ \\
\hline
\end{tabular}

\section{DISCUSSION}

The limited knowledge of death people regarding health emerges from ineffective communication with health professionals. Such limitation affects and impairs the quality of life and self-care, so that death people need interpreters or family members to mediate communication with health professionals ${ }^{(8)}$.

In this context, it is relevant that health professionals have minimal knowledge of Libras to be successful in communicating with death people and to improve the quality of care provided ${ }^{(5)}$. Such knowledge must be offered during the training process, so that it deals with the preparation of future professionals to meet the real demands of health services.

The regions of Brazil with the highest offer of Libras course in higher education nursing courses were the Southeast and Northeast, while the minority of offer occurred in the North. The predominance of the Northeast and Southeast regions and the lowest amount of supply in the North were found in a study on the teaching of health surveillance in nursing training ${ }^{(11)}$. Thus, when understanding the need for health training that contemplates Libras, with the singularities inherent to each regional specificity, the relevance of increasing the offer of this course in undergraduate nursing courses in all regions of the country is ratified, especially in the North.

Regarding the location of the courses, there was a predominance in municipalities in the countryside of the states. This characteristic is due to the scenario of expandability of undergraduate courses in Brazil, the policy of internalization of higher education and the development of social programs, which promoted access and less evasion to Higher Education Institutions (HEls) ${ }^{(12)}$. When considering the relevance of using pedagogical resources and strategies that are selected for teaching in nursing based on research results that point out the most effective options for achieving pedagogical goals, and observing the high number of nursing courses that are not located in the capitals, it is pertinent that research on nursing education is not limited to the scenarios of such capitals, but also occurs in courses that are found in countryside cities so that scientific evidence about nursing education directs the performance of professors working in this context.

Most of the nursing courses that had a Libras course were offered by private educational institutions, with statistical significance. This result converges with that found in a study that characterized the teaching of bioethics in undergraduate nursing course $^{(13)}$. The quantitative increase in private education makes these institutions responsible for the training of most professionals; therefore, the relevance of private institutions being analyzed in research on nursing education is ratified.
In relation to the semester of the nursing course in which the course is offered, there was a predominance of offers in the second half of the course, more specifically in the eighth module/semester. This finding differs from a study on the teaching of Thanatology in nursing, whose results showed that the offer of such content occurs in the first semesters of the course $\mathrm{e}^{(14)}$. It is understood that the offer of curricular components in higher education nursing courses is based on justification regarding the interdisciplinary context and logical sequence of knowledge and skills necessary for training. Thus, it is pointed out that nursing students can face assistance to deaf patients in the first semesters of the course, so it is relevant that the Libras course offer occurs in the initial semesters of training.

It was observed that the offer of teaching Libras in Brazilian undergraduate nursing courses took place through a mandatory course. This finding is similar to that found in a research carried out in Australia on the teaching of intellectual disabilities in the nursing curriculum ${ }^{(15)}$. Teaching Libras in undergraduate courses is important, as it can represent the first contact of academics with sign language. Despite not being proficient, academics will have the possibility to establish minimal communication with death people, will be able to understand death people culture and be sensitized about their health exclusion ${ }^{(16)}$.

Regarding the course load of Libras, there was a predominance of the offer occurring in forty hours. When considering that the translation of knowledge in Libras requires investment of time, it is necessary that researches investigate the effectiveness of Libras courses in their different workloads so that the best workload to be invested in teaching sign language is known within the limitations of the workload available in higher education nursing courses.

\section{Study limitations}

The study had as a limitation the search for curricular matrices to have occurred through virtual access, so that the reality of educational institutions that did not have the matrix for online access may differ from that found. Moreover, the results found were related to nursing courses so that Libras courses offered in other health courses may have another characterization. Another limitation to be pointed out refers to the scarcity of studies in the area addressed (teaching Libras in nursing), which made it difficult to compare and discuss the findings; therefore, the results of the present study were compared and discussed with the research findings on the teaching of other curricular themes/ components in nursing education.

\section{Contributions to nursing, health, and public policy}

The present study contributes to the advancement of the state of the art regarding nursing education, Libras teaching and inclusion in the health of death people, given the characterization of Libras teaching in undergraduate nursing courses, which covered all regions of the country and courses from public and private institutions. It also presents scientific evidence on a theme that is not widely considered in research, but has relevance to society and health. Thus, it is relevant for professionals involved in teaching Libras and in nursing education/training, who can 
plan curriculum changes and/or implement Libras courses in nursing courses.

\section{CONCLUSIONS}

Libras teaching was found, predominantly, in nursing courses from private institutions (87.2\%), located in the Southeast (36\%), from courses offered as a mandatory component (82\%), available to be taken in the second half of the course $(46.7 \%)$, more specifically in the eighth semester (15.9\%). The shortest workload found was 15 hours, the longest, 88 , with a median of 40 hours. The course offer proved to be associated with the variable "public or private category".

It is necessary to carry out research that contemplates the best workload that the Libras course needs to have in higher nursing courses so that it is possible to equip the academic with knowledge and skills that enable minimal communication with death people. Moreover, it is relevant that qualitative research investigates subject issues, such as experience, feelings, and opinion of academics attending the course and death people who interact with such academics. It is relevant to carry out research that contemplates the challenges and potential for offering a Libras curriculum component in undergraduate nursing courses and that compares the advantages and disadvantages, as well as the possible consequences of their offer in a mandatory and optional way, in addition to verify if there is an association between the course offer and the MEC assessment concept. It also highlights the need for planning and investment to offer Libras courses in more nursing courses, mainly in the North and South.

\section{REFERENCES}

1. World Health Organization. Deafness and hearing loss [Internet]. World Health Organization; 2018 [cited 2020 Jan 16]. Available from: http://www.who.int/news-room/fact-sheets/detail/deafness-and-hearing-loss

2. Chininthorn P, Glaser M, Tucker WD, Diehl JC. Exploration of deaf people's health information sources and techniques for information delivery in Cape Town: a qualitative study for the design and development of a mobile health app. JMIR Hum Factors. 2016;3(2):e28. https:// doi.org/10.2196/humanfactors.6653

3. Beltrami CM, Moura MC. A educação do surdo no processo de inclusão no Brasil nos últimos 50 anos (1961-2011). REB [Internet]. 2015 [cited 2020 Jan 16];8(1):146-61. Available from: https://revistas.pucsp.br/reb/article/view/19930

4. Galindo-Neto NM, Áfio ACE, Leite SS, Silva MG, Pagliuca LMF, Caetano JA. Technologies for health education for the deaf: integrative review. Texto Contexto Enferm. 2019;28:e20180221. https://doi.org/10.1590/1980-265X-TCE-2018-0221

5. Santos AS, Portes AJF. Perceptions of deaf subjects about communication in Primary Health Care. Rev Latino-Am Enfermagem. 2019;27:e3127. https://doi.org/10.1590/1518-8345.2612.3127

6. Fitzmaurice C, Allen C, Barber RM, Barregard L, Bhutta ZA, Brenner H, et al. Global, regional and national cancer incidence, mortality, years of life lost, years lived with disability, and disability-adjusted life-years for 32 cancer groups, 1990 to 2015: a systematic analysis for the global burden of disease study. JAMA Oncol. 2017;3(4):524-48. https://doi.org/10.1001/jamaoncol.2016.5688

7. Zander M. Public health and disability studies. Public Health Forum. 2017;25(4):259-61. https://doi.org/10.1515/pubhef-2017-0041

8. Naseribooriabadi T, Sadoughi F, Sheikhtaheri A. Barriers and facilitators of health literacy among d/deaf individuals: a review article. Irã J Saúde Pública [Internet]. 2017 [cited 2020 Jan 16];46(11):1465-74. Available from: https://www.ncbi.nlm.nih.gov/pmc/articles/PMC5696685/

9. Galindo-Neto NM, Alexandre ACS, Barros LM, Sá GGM, Carvalho KM, Caetano JÁ. Creation and validation of an educational video for deaf people about cardiopulmonary resuscitation. Rev Latino-Am. Enfermagem. 2019; 27: e3130. https://doi.org/10.1590/1518-8345.2765.3130

10. Mattia BJ, Kleba ME, Prado ML. Nursing training and professional practice: an integrative review of literature. Rev Bras Enferm. 2018;71(4):2039-49. https://doi.org/10.1590/0034-7167-2016-0504

11. Lôbo CDA, Cunha MCSO, Ponte VA, Costa EC, Araújo MFM, Araújo TM. The teaching of sanitary surveillance in the training of nurses. Rev Esc Enferm USP. 2018;52:e03387. https://doi.org/10.1590/S1980-220X2017035803387

12. Gomes V, Taylor MLM, Saraiva EV. O ensino superior no Brasil: breve histórico e caracterização. Ciênc Trópico [Internet]. 2018 [cited 2020 Jan 18];42(1):127-52. Available from: https://fundaj.emnuvens.com.br/CIC/article/view/1647

13. Pacheco FC, Aguiar BRL, Araújo MC, Ramos CA, Protasio FC, Guillhem DB. Curricular analysis of bioethics teaching in undergraduate nursing courses in Brazil. Rev Baiana Enferm. 2019;33:e27684. https://doi.org/10.18471/rbe.v33.27684

14. Moura LVC, Passos ECS, Santos RMM, Santa Rosa DO, Nascimento Sobrinho CL. Thanatology teaching in undergraduate nursing programs. Rev Baiana Enfermagem. 2018;32:e20888. https://doi.org/10.18471/rbe/v32.20888

15. Trollor JN, Eagleson C, Turner B, Salomon C, Cashin A, lacono T, et al. Intellectual disability health content within nursing curriculum: an audit of what our future nurses are taught. Nurs Educ Today. 2016;45:72-9. https://doi.org/10.1016/j.nedt.2016.06.011

16. Iachinski LT, Berberian AP, Pereira AS, Guarinello AC. Libras discipline inclusion in graduation courses: future teacher's vision. Audiol Commun Res. 2019;24:e2070. https://doi.org/10.1590/2317-6431-2018-2070 